\title{
Fibrous dysplasia originating from the middle ear
}

\author{
Orta kulak orijinli fibröz displazi
}

\author{
Ekrem Karakaş ${ }^{1}$, Nihat Kılıçaslan ${ }^{1}$, Ömer Karakaş ${ }^{1}$, Ferhat Bozkuş ${ }^{2}$
}

\section{ABSTRACT}

Fibrous Dysplasia is rarely seen in adults. The anterior craniofacial bones are more commonly involved than more lateral or posterior regions. Loss of vestibular function, tinnitus and hearing loss may be seen associated with sphenoid and temporal bone involvement. We aimed to report the case of a thirty-year-old female patient with fibrous dysplasia located in the middle ear. J Clin Exp Invest 2013; 4 (2): 219-220

Key words: CT, fibrous dysplasia, middle ear

\section{CASE}

A 30-year-old female patient presented to otolaryngology department with complaints of diminished hearing lately. Hearing tests are used to determine conductive hearing loss. An expansile bone lesion with appearance of ground glass was observed in the left ossicles and epitympanum on the temporal bone Computed Tomography (CT) images. There was fusion of the ossicles, affecting almost all of them (Figure 1, 2). Fibrous dysplasia of the middle ear was diagnosed by typical CT findings.

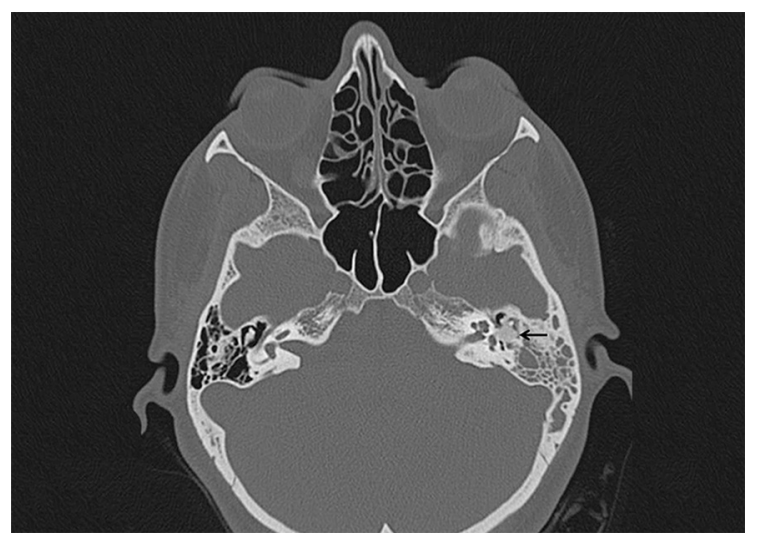

Figure 1. On axial temporal bone CT images, a bone lesion was observed in the ossicles area with expanded and ground-glass appearance. Aeration of the mastoid cells was lost because of soft tissue densities.

\section{ÖZET}

Fibröz displazisi nadiren erişkinlerde görülür. Anterior kraniofasial kemikler, lateral ve posterior bölgelerden daha sık olarak tutulur. Vestibüler fonksiyon kaybı, tinnitus ve işitme kaybı, sfenoid ve temporal kemik tutulumu ile ilişkili görülebilir. Biz, orta kulakta yerleşimli fibröz displazili otuz yaşında kadın vakayı sunmayı amaçladık.

Anahtar kelimeler: BT, fibröz displazi, orta kulak

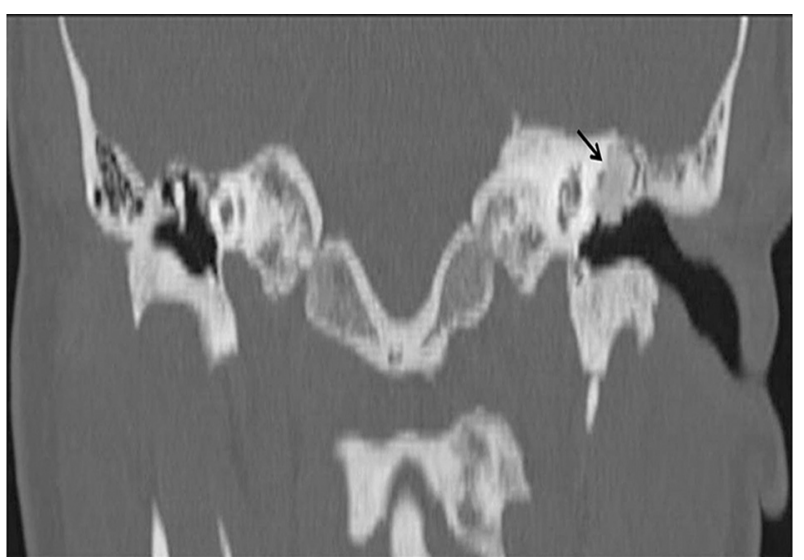

Figure 2. On coronal reformatted CT image, a bone lesion was observed in the left ossicles and epitympanum with expanded and ground-glass appearance.

\section{DISCUSSION}

Fibrous dysplasia is a developmental anomaly of unknown cause with bone mesenchymal origin. Generally seen in childhood or adolescence, fibrous dysplasia is a benign fibro-osseous lesion of the bone. It is rarely seen in adults [1]. In our case, the onset of symptoms was at 30 years of age. The craniofacial involvement in fibrous dysplasia is frequently seen in the frontal, ethmoidal, sphenoid and maxillary bones. The occipital and temporal bones

${ }^{1}$ Harran University, Faculty of Medicine, Department of Radiology, Şanlıurfa, Turkey

${ }^{2}$ Harran University, Faculty of Medicine, Department of Otolaryngology, Şanlıurfa, Turkey

Correspondence: Ekrem Karakaş,

Harran Üniversitesi Tıp Fakültesi Radyoloji Bölümü, Şanlıurfa, Türkiye Email: karakasekrem@yahoo.com

Received: 02.12.2012, Accepted: 19.12.2012

Copyright (C) JCEI / Journal of Clinical and Experimental Investigations 2013, All rights reserved 
are rarely affected. Loss of vestibular function, tinnitus and hearing loss may be seen associated with sphenoid and temporal bone involvement. Conductive hearing loss associated with temporal bone involvement is rare,[2] as in our case. Particularly for the temporal bone, CT should be the first preferred modality to determine the lesion, and to evaluate the spread and in follow-up [3]. Affected bones are usually expanded with an intact cortex and lose the normal cortico-medullary differentiation, being replaced classically by a homogeneous ground glass appearance, although mixed lucencies and sclerosis are also common on the CT and radiography. The observation of a typical expansile bone lesion with appearance of ground glass on the radiograph and CT does not require an indication for biopsy $[3,4]$. In the differential diagnosis, solitary unicameral cyst, nonosteogenic fibroma, giant cell tumor of bone, aneurysmal bone cyst, adamantinoma of long bones, eosinophilic granuloma, plasma cell myeloma, fibro-osseous lesions and sarcomatous neoplasm must be considered [5,6]. In our case, the differential diagnosis of fibrous dysplasia was made by typical CT findings. Hence, there was not felt to be a need for a biopsy. In conclusion, it should be borne in mind that fibrous dysplasia involving the middle ear ossicles may lead to conductive hearing loss.

\section{REFERENCES}

1. Sakamoto A, Oda Y, Iwamoto Y, Tsuneyoshi M. A comparative study of fibrous dysplasia and osteofibrous dysplasia with regard to expressions of c-fos and cjun products and bone matrix proteins: a clinicopathologic review and immunohistochemical study of c-fos, c-jun, type I collagen, osteonectin, osteopontin, and osteocalcin. Hum Pathol 1999;30:1418-1426.

2. Megerian CA, Sofferman RA, McKenna MJ, et al. Fibrous dysplasia of the temporal bone: ten new cases demonstrating the spectrum of otologic sequelae. Am J Otol 1995;16:408-419.

3. Fitzpatrick KA, Taljanovic MS, Speer DP et-al. Imaging findings of fibrous dysplasia with histopathologic and intraoperative correlation. AJR Am J Roentgenol 2004;182:1389-1398.

4. Bulakbasi N, Bozlar U, Karademir I, et al. CT and MRI in the evaluation of craniospinal involvement with polyostotic fibrous dysplasia in McCune-Albright syndrome. Diagn Interv Radiol 2008;14:1177-1181.

5. Friedman I. Diseases of the Temporal Bone. ScottBrown's Otolaryngology, General Editor Kerr AG. Vol. 3 Edited by Booth JB. Sixth Edition, Oxford, Boston, Johannesburg, Melbourne, New Delhi, Singapore, Butterworth-Heinmann (Publishers) Ltd. 1997:3/4/4143.

6. Nager GT, Kennedy DW, Kopstein E. Fibrous Dysplasia: A review of the disease and its manifestations in the temporal bone. Ann Otol Rhinol Laryngol 1982:91:1-52. 